\title{
Crepuscular dawn
}

Paul Virilio and Sylvere Lotringer (translated by Mike Taurmina)

Semiotext(e), Los Angeles and New York, 2002, 164pp.

ISBN: $158435013 \mathrm{X}$.

Contemporary Political Theory (2004) 3, 120-121. doi:10.1057/palgrave.cpt.9300088

This is a very important publication for anyone engaged by the work of Paul Virilio. It should also stimulate anyone interested in questions and problems that pertain to the phenomenon of war and its beguiling relation to modernity and globalization. In the now well-established form of a series of dialogues with Sylvere Lotringer, Virilio again discusses the relations between some of the major themes and issues that have defined his output: war, architecture, technology, science, and terrorism. The discussion of Virilio's work in architecture during the early period of his career is exceptional, and particularly welcome given his customary reticence to talk on that subject. Indeed, the juxtaposition of Virilio's thoughts on architecture with his contemporary ruminations on terrorism is compelling, and certain to provoke controversy.

The early conversations between Virilio and Lotringer detail Virilio's forays into architecture and urban design during the 1960s. Then, Virilio was particularly concerned with challenging the orthogonal bias that existed in architectural trends of the period. It was, as he describes, a bias that had culminated in the forms of architecture that then defined that most Euclidean of structures, the skyscraper tower. Virilio identified the privileging of vertical forms especially with the design of the city of New York. So much so that he described New York as representative of a then increasing trend toward the 'Babelization of the city'. In response, Virilio developed an 'oblique architecture' based around the creation of forms that are slanted or inclined in deviation from the vertical forms that were then prevalent. As Lotringer describes in her excellent introduction to the book, Virilio conceived his 'oblique architecture' as a form of 'warfare' to be waged upon the 'aberration' of 'the Tower'.

While many of Virilio's seminal ideas on the possibilities of creating oblique architectural forms have been taken up by a younger generation of architects (Lars Spuybroek in particular), Virilio himself has largely left those concerns behind. His subsequent writings have been dominated by a dogged insistence upon what he perceives to be the diabolical implications of technologies for humankind. Ever the political realist, Virilio argues that every form of technology necessarily invokes its own particular form of 'accident'. Arguing 
along these lines, disastrous events are understood in terms of their technological conditions of occurrence. Electricity results in Chernobyl, the luxury liner results in the sinking of the Titanic, the passenger airliner in $9 / 11$, and so on. However, he argues that the accident of technology is now to be understood in a new context. In the later conversations, Virilio discusses how the accident has become 'the new form of warfare.' The instruments of warfare are, he argues, no longer weapons but machines that provoke accidents. In this context, he expresses sympathy for the manifesto of the Unabomber (while disassociating himself from the means employed by the Unabomber) and locates the attack on the World Trade Center within a new genre of wars of globalization based upon the invocation of the accident.

How are we to make sense of this? The juxtaposition of Virilio's ideas on architecture, warfare, technology, and terrorism is highly provocative in that they suggest some form of congruency between the attack on the World Trade Center and Virilio's own conception of resistance to globalization. However, the precise nature of that congruency is very much open to debate, and it would be crude to the point of absurdity to attempt to reduce the complexities of Virilio's ideas to the status of an ideology. However, it should at least serve to reinforce the point that the genealogy of international terrorism implicates ideas, forces and forms with origins in the West itself, as opposed to its popular depiction as a phenomenon to be understood in terms purely antipathetic to the West. Virilio's rage against technology, globalization, and the militaryindustrial complex, is very much shaped by his apocalyptic Christianity and a particular understanding of the roles and possibilities of critique that, ironically, recalls E.H. Carr's depiction of the dialectic between realism and idealism. The revelation of the extreme negative implications of technology in events such as the attack on the World Trade Center are, for Virilio, testimony to the impossibility of creating any positive force without in turn invoking a commensurate negative. Proceeding from this basis, Virilio argues that the revelation of the accident, the invocation of negative principles, is a positive task, both theoretically and practically. This is, of course, to employ the tragic realist ontology that Virilio shares with Carr to ends rarely engaged with by the discipline of international relations, to which political realism is most closely associated. For this reason alone, Crepuscular Dawn is a must-read for anyone engaged in testing the limits of international political thought.

Julian Reid

Department of Political Studies, School of Oriental and African Studies. 